\title{
ОЛЕКСАНДР ВОРОХАСВ
}

ORCID 0000000339434300 a.vorokhaiev@gmail.com аспірант

Національний університет «Чернігівський колегіум» імені Т. Г. Шевченка вул. Гетьмана Полуботка, 53, м. Чернігів

\section{ПЕДАГОГІЧНІ УМОВИ ФОРМУВАННЯ ЗДОРОВ'ЯЗБЕРЕЖУВАЛЬНОӦ КОМПЕТЕНТНОСТІ МАЙБУТНІХ СОЦАЛЬНИХ ПРАЦІВНИКІВ}

\begin{abstract}
Проаналізовано педагогічні умови формування здоров'язбережувальної компетентності майбутніх сочіальних працівників. Вказано, щуо ие сукупність заходів, реалізація яких забезпечує сформованість здоров'язбережувальної компетентності майбутніх соиіальних працівників у процесі професійної підготовки. Визначено стан дослідження проблеми в сучасній науковій вітчизняній літературі. Обгрунтовано, щзо здоров'язбережувальна компетентність - це комплекс знань, умінь, ставлень та цінностей, які спрямовані на збереження й зміцнення здоров'я. Виокремлено наступні педагогічні умови формування здоров'язбережувальної компетентності майбутніх соиіальних працівників у процесі професійної підготовки: підвищення мотивації майбутніх соиіальних працівників до здоров 'язбережувальної діяльності; створення здоров 'язбережувального середовища, що спрямоване на виховання свідомого та дбайливого ставлення до власного здоров'я; урізноманітнення форм здоров'язбережувальної діяльності майбутніх соиіальних працівників у позааудиторній роботі.
\end{abstract}

Ключові слова: здоров'язбережувальна компетентність, педагогічні умови, майбутні соціальні працівники, студенти, заклади вищої освіти.

\section{АЛЕКСАНДР ВОРОХАЕВ}

аспирант

Национальный университет «Черниговский коллегиум» имени Т. Г. Шевченко ул. Гетьмана Полуботка, 53, г. Чернигов

\section{ПЕДАГОГИЧЕСКИЕ УСЛОВИЯ ФОРМИРОВАНИЯ КОМПЕТЕНТНОСТИ СОХРАНЕНИЯ ЗДОРОВЬЯ БУДУЩИХ СОЦИАЛЬНЫХ РАБОТНИКОВ}

\begin{abstract}
Проанализированы педагогические условия формирования компетентности по сохранению здоровья будущчих социальных работников. Указано, что это совокупность мероприятий, реализачия которых обеспечивает сформированность компетентности по сохранению здоровья будущих соииальных работников в процессе профессиональной подготовки. Определено состояние исследования проблемь в современной научной украинской литературе. Обосновано, что компетентность по сохранению здоровья - это комплекс знаний, умений, отношений и иенностей, направленных на сохранение и укрепление здоровья. Определень следующие педагогические условия формирования компетентности сохранения здоровья будущих сочиальных работников в прочессе профессиональной подготовки: повыщение мотивации будущих социальных работников к деятельности по сохранению здоровья; создание среды для сохранения здоровья, направленное на воспитание сознательного и бережного отношения к собственному здоровью; разнообразие форм деятельности по сохранению здоровья будущих сочиильных работников в внеаудиторной работе.
\end{abstract}

Ключевые слова: компетентность сохранения здоровья, педагогические условия, будущие социальные работники, студенты, высшие учебные заведения.

\section{OLEKSANDR VOROKHAEV}

Postgraduate Student

T. H. Shevchenko National University «Chernihiv Colehium» 


\section{PEDAGOGICAL CONDITIONS OF THE HEALTHCARE COMPETENCE FORMATION OF FUTURE SOCIAL WORKERS}

The article analyzes the pedagogical conditions of competence forming to preserve the future social workers' health. It is determined that this is a set of measures, the implementation of which ensures that the competence of preserving the health of future social workers in the process of vocational training is formed. Purpose of the article: To analyze the pedagogical conditions of competence forming of preserving the health of students of the specialty "Social work». Research methods: theoretical analysis and generalization of scientific literature data to substantiate the essence of the concept of «competence to maintain health»; testing, valeological monitoring, pedagogical experiment of pedagogical conditions of formation of competence of preservation of future social workers' health. Scientific novelty: the process of forming the competence of preserving the health of students of the specialty "Social work》 during mastering the disciplines in the conditions of magistracy is analyzed. The state of research of the problem in modern scientific domestic and foreign literature is determined. The article complemented the methodology and tools for further empirical research on some aspects of health competency formation. Health competence is a set of knowledge, skills, attitudes and values that aim to preserve and promote health. The following pedagogical conditions of preserving health competence formation of future social workers in the course of vocational training are substantiated: increase of future social workers' motivation for activity which preserves health; creating a health preservation environment that fosters a conscious and caring attitude to one's own health; diversification of the forms of health activities of future social workers in out-of-class work. Important components of student health are also: intensifying the health of teachers and students; the use of technologies that will help to shape the competence of students' health; organization of constructive interaction between the subjects of the educational process, aimed at forming the competence for preserving the future specialists' health; conducting pedagogical diagnostics of students' education regarding health competence; the use of reflection in the educational process of higher education institutions.

Keywords: health competence, pedagogical conditions, future social workers, students, higher education institutions.

Враховуючи негативні тенденції в стані здоров’я населення України, внаслідок соціально-економічних, екологічних i політичних проблем, державна стратегія розвитку суспільства повинна бути спрямована на створення здоров'язбережувального освітнього середовища. Формування здоров'язбережувальної компетентності майбутніх соціальних працівників $є$ складним та довготривалим процесом. Він має міждисциплінарний i багатоаспектний характер, який вимагає спеціальної підготовки. Таку підготовку необхідно здійснювати впродовж всього періоду навчання у закладах вищої освіти (ЗВО) шляхом створення відповідних педагогічних умов, що забезпечать залучення студентів до процесу здоров'язбереження.

Актуальність проблеми обумовлена сучасним рівнем розвитку вищої освіти, який актуалізує педагогічні проблеми, пов'язані 3 формуванням здоров'язбережувальної компетентності шляхом набуття студентами спеціальності «Соціальна робота» навичок збереження, зміцнення, використання здоров'я та дбайливого ставлення до нього, свідомого ведення здорового способу життя.

Питанням здоров’язбереження присвячені праці Ю. Бойчука [1], С. Ермакова [5], Ж. Козіної [7], Ю. Носко [9], В. Оржеховської [10], О. Отравенко [11] та інших українських науковців, які засвідчили зростаючий інтерес до проблеми дослідження. Важливими для нашого дослідження є дисертаційні роботи вітчизняних вчених, які вивчали різні аспекти, включаючи педагогічні умови формування здоров'язбережувальної компетентності: О. Вакуленко [2], В. Гриценко [4], Л. Кальченко [6], М. Лєхолєтової [8], М. Чайковського [13], Ю. Чернецької [14], В. Штифурак [15].

Мета статті - проаналізувати педагогічні умови формування здоров'язбережувальної компетентності студентів спеціальності «Соціальна робота».

Наукова новизна дослідження полягає в тому, що проаналізовано процес формування здоров'язбережувальної компетентності студентів спеціальності «Соціальна робота» під час опанування дисциплін в умовах магістратури. Визначено стан дослідження проблеми в сучасній науковій вітчизняній та зарубіжній літературі. Доповнено методологію та інструментарій подальших емпіричних досліджень деяких аспектів формування соціальної складової здоров'я в процесі здоров'язбереження. 
Натепер обгрунтоване занепокоєння викликає стан здоров'я студентської молоді в Україні. За даними Міністерства охорони здоров'я кількість хронічно хворих дітей збільшується за роки навчання у 2,5 рази. Негативно впливає на стан здоров'я учнів та студентів зниження рухової активності, гіподинамія, гіпокінезія, обумовлені порушенням норм здорового способу життя та недостатністю самостійних занять фізичними вправами [5, с. 60; 7 , c. $153 ; 12$, с. 47$]$.

Навчання в умовах здоров'язбережувальної педагогіки містить у собі передачу знань, умінь і навичок, які сприяють формуванню уяви про здоров'язбереження, гармонійне поєднання духовного та фізичного розвитку, що допоможе надалі учасникам педагогічного процесу охороняти і зберігати як своє власне здоров'я так і здоров'я оточуючих людей [10, с. 30].

Здоров'язбережувальна компетентність - це комплекс знань, умінь, ставлень та цінностей, які спрямовані на збереження й зміцнення здоров'я. Більшість українських дослідників розглядають компетентність здоров'язбереження, як основу буття людини, де основним є усвідомлення важливості здоров'я, здорового способу життя для всієї життєдіяльності особистості [1, с. $154 ; 9$, с. $80 ; 12$, с. 48].

Впровадження здоров'язбережувальних освітніх технологій у навчально-виховний процес ЗВО пов'язано 3 використанням медико-гігієнічних, фізкультурно-оздоровчих, лікувально-оздоровчих, соціально-адаптованих, екологічних, валеологічних технологій та технологій забезпечення безпеки життєдіяльності.

Сутність здоров'язбережувальних технологій постає в комплексній оцінці умов виховання і навчання, які дозволяють забезпечувати гарний стан здоров'я молодих людей, дбати про високий рівень їхньої самореалізації, навичок здорового способу життя; здійснювати моніторинг показників індивідуального розвитку, прогнозувати можливі зміни здоров'я i проводити відповідні психолого-педагогічні, коригувальні, здоров'язбережувальні, рекреаційні заходи 3 метою забезпечення якості навчальної та професійної діяльності учасників педагогічного процесу.

Визначення педагогічних умов формування здоров'язбережувальної компетентності майбутніх соціальних працівників потребує уточнення поняття «педагогічні умови».

Педагогічні умови вчені визначають як: заходи, спрямовані на «формування здорового способу життя, підвищення соціальної активності, розширення кола знайомств і сфери особистісних контактів, організацію відпочинку та дозвілля, вирішення проблемних соціальних питань» [13, с. 11] «сукупність певних обставин, що створюються у середовищі закладу освіти під впливом зовнішніх та внутрішніх чинників та забезпечують взаємодію старших підлітків 3 цим середовищем, засвоєння ними соціального досвіду, залучення до соціуму, збереження здоров’я, розвиток свідомості й здатності до самовизначення особистості» [14, с. 13].

О. Отравенко називає наступні педагогічні умови формування здоров'язбережувальної компетентності майбутніх соціальних працівників: забезпечення взаємозв'язку теоретичної i практичної підготовленості студентів за допомогою системного формування теоретичних знань про стан здоров'я та свідоме ведення здорового способу життя; створення здоров'язбережувального середовища, що спрямоване на виховання свідомого та дбайливого ставлення до власного здоров'я; позитивне ставлення студентів спеціальності «Соціальна робота» до самостійних занять фізичними вправами; розробки системи засобів, що спрямовані на формування здоров'язбережувальної компетентності студентів з впровадженням методики проведення розтягувань та дихальних вправ [12, с. 48].

Л. Кальченко вкладає у зміст педагогічних умов «спеціально організовані обставини i можливості для діяльності, від наявності або зміни яких залежить ефективність певного процесу» [6, с. 152].

Проаналізувавши теоретичні положення досліджень українських вчених [2;3; 4; 8;9], вважаємо обгрунтованими наступні педагогічні умови формування здоров'язбережувальної компетентності майбутніх соціальних працівників у процесі професійної підготовки, які визначила М. Лехолетова: підвищення мотивації майбутніх соціальних працівників до здоров'язбережувальної діяльності; створення здоров'язбережувального середовища, що спрямоване на виховання свідомого та дбайливого ставлення до власного здоров'я; урізноманітнення форм здоров'язбережувальної діяльності майбутніх соціальних працівників у позааудиторній роботі $[8$, c. 110]. 
Окреслені педагогічні умови взаємопов'язані між собою і мають діяти у сукупності для забезпечення якості формування здоров'язбережувальної компетентності майбутніх соціальних працівників у процесі професійної підготовки.

Педагогічна умова підвищення мотивації майбутніх соціальних працівників до здоров'язбережувальної діяльності, на нашу думку, у формуванні здоров'язбережувальної компетентності є визначальною, оскільки мотивація сприяє професійному розвитку студентів спеціальності «Соціальна робота», підтримує бажання йти до поставленої мети та досягати іiі.

Автор теорії людської мотивації та ієрархії потреб, А. Маслоу писав, що «пріоритетними для людини є потреби нижчих рівнів, задовольнивши які відбувається формування потреб вищих рівнів». Формування здоров'язбережувальної компетентності особистості доцільно здійснювати починаючи від задоволення іiі базових потреб до більш значущих цінностей здоров'я. Як зауважує М. Лехолетова, «...А. Маслоу не вважав ієрархію потреб фіксованою, він підкреслював провідне значення індивідуальних особливостей кожної людини» [8, с. 111].

Для реалізації цієї умови було впроваджено в освітній процес психолого-педагогічного факультету Національного університету «Чернігівський колегіум» імені Т. Г. Шевченка дисципліну «Формування здорового способу життя», що дозволило студентам спеціальності «Соціальна робота» ознайомитись 3 усіма аспектами індивідуального здоров'я людини, навчитися усвідомлювати стан свого здоров'я з урахуванням підвищення мотивації майбутніх соціальних працівників до здоров'язбережувальної діяльності.

Мотив - це усвідомлена необхідність майбутніх соціальних працівників у сформованості здоров'язбережувальної компетентності та мотивація до організації власної здоров'язбережувальної діяльності, тобто мотиви майбутніх соціальних працівників $\epsilon$ основою їхньої мотивації [8, с. 111].

Створення здоров'язбережувального середовища, що є наступною педагогічною умовою, спрямоване на виховання свідомого та дбайливого ставлення до власного здоров'я, позитивного ставлення майбутніх соціальних працівників до самостійних занять фізичними вправами. Емоційно-комфортне освітнє середовище - це сукупність умов, за яких відбувається ефективна навчально-пізнавальна діяльність суб'єктів педагогічного процесу [8, с. 111]. Це передусім: позитивна взаємодія викладачів і студентів; участь всього колективу групи в обговоренні вирішення психолого-педагогічних проблем; пріоритетність дискусійних обговорень питань на практичних заняттях, коли студенти мають змогу вільно висловлювати свої думки. Завдяки створенню сприятливого, емоційно-комфортного освітнього середовища майбутні соціальні працівники набувають здатності до рефлексії своєї здоров'язбережувальної діяльності, активної позиції від усвідомлення важливості збереження здоров'я до оперування та конструктивного коректування поведінки і прогнозування іiі результатів, самовиховання, самоосвіти, самооцінки, самоаналізу. Все це разом є основою для плідних міжособистісних взаємодій, можливостей для вільної комунікації, партнерського співробітництва між викладачем та студентом [8, с. 113].

О. Отравенко [11, с. 251] вважає, що прагнучи створити комфортне середовище для всіх учасників освітнього процесу, необхідно адаптувати досвід різних ЗВО та їхніх методик викладання навчальних дисциплін, які базуються на здоров'язбережувальних технологіях. 3 метою підвищення здоров'язбережувальної компетентності майбутніх соціальних працівників, підвищення рівня їх здоров'я та психолого-педагогічної підготовки, адаптації до реалій нового життя в умовах освітнього здоров'язбережувального середовища, було впроваджено навчальний курс «Формування здорового способу життя», бесіди «Впровадження здоров'язбережувальних технологій у 3ВО» i «Попередження негативних звичок у студентів»,самостійні заняття фізичними вправами на основі особистісно орієнтованого та диференційованого підходів.

Педагогічною умовою розробки системи засобів, які спрямовані на формування здоров'язбережувальної компетентності студентської молоді $\epsilon$ урізноманітнення форм здоров'язбережувальної діяльності майбутніх соціальних працівників у позааудиторній роботі. Наукові дослідження та статистика свідчить, що лише 7-8 студентів з кожних 25, віком від 20 до 22 років, не мають порушень постави [11, с. 252]. Отже, нині, під час формування здоров'язбережувальної компетентності майбутніх соціальних працівників бажано включати «в самостійні заняття фізичною культурою вправи на: розвиток гнучкості та рухомості хребетного стовпа, кульшових і плечових суглобів; створення м'язового корсету; розвиток і удосконалення 
м'язово-суглобового відчуття через формування стереотипу правильного положення тіла під час ходьби, сидіння, стояння, виконання різних видів діяльності; дихальні вправи» [12, с. 50].

необхідно звернути особливу увагу на правильне дихання та послідовність і тривалість дій. Розтягування має бути нерізким, без зайвого зусилля і може виконуватися як на вдиху, так i на видиху. Не можна виконувати розтягування в швидкому темпі. Вітчизняні науковці вважають, що ці вправи ефективно впливають на збереження й зміцнення здоров'я учнів та студентів [12, с. 50$]$.

Важливим аспектом професійної підготовки майбутніх соціальних працівників, на нашу думку, є сформованість в них системи знань, умінь і навичок щодо збереження, зміцнення і підтримки власного здоров'я.

Важливими педагогічними умовами формування здоров'язбережувальної компетентності студентів у ЗВО є: створення освітньо-оздоровчого, інтерактивного освітнього середовища (соціуму); систему інтерактивних технологій соціально-педагогічного супроводу системної здоров'язбережувальної діяльності їі суб'єктів [3, с. 215-222].

Маємо констатувати, що викладачі, внаслідок своїх професійних можливостей, мають змогу створювати педагогічні умови для всебічного розвитку студентів спеціальності «Соціальна робота», посилюючи у майбутніх соціальних працівників зміст соціального виховання, спрямованого на здоров'язбережувальну діяльність. При цьому, як зауважує О. Вакуленко, варто враховувати «труднощі соціального становлення» особистості, а також «засоби варіативності запобігання соціальних проблем, пов'язаних з ризиками поведінки та здоров'я» [2, с. 20]. Зміст занять із соціально-педагогічних дисциплін, які викладають на кафедрах соціальної роботи ЗВО, допоможе майбутнім соціальним працівникам у процесі професійної підготовки, в теорії та на практиці опанувати власний здоров'язбережувальний потенціал, навчитися його застосовувати, а отже, підвищити рівень здоров'язбережувальної компетентності, що особливо важливо для нашого дослідження [8, с. 109].

В. Штифурак, розглядаючи соціально-педагогічні фактори організації виховної роботи у ЗВО, вказує на «необхідність формувати ціннісні орієнтації, професійне становлення і кар'єрне зростання студентської молоді, утверджувати принципи здорового способу життя» [15, с. 21].

Отже, на основі проведеного аналізу педагогічні умови формування здоров'язбережувальної компетентності майбутніх соціальних працівників розглядаємо як сукупність заходів, реалізація яких забезпечує сформованість здоров'язбережувальної компетентності майбутніх соціальних працівників у процесі професійної підготовки.

Здоров'язбережувальна компетентність майбутніх соціальних працівників має потенціал в забезпеченні здоров'язбережувальної спрямованості змісту підготовки студентів у ЗВО. Це передбачає оволодіння майбутніми фахівцями професійними здоров'язбережувальними знаннями та вміннями, а саме: стабільні знання про здоров'я та впливу на нього негативних факторів, причини та наслідки шкідливих звичок, їхню профілактику.

Важливими складовими збереження здоров'я студентів $3 \mathrm{BO} \epsilon$ : активізація здоров'язбережувальної діяльності викладачів і студентів; використання технологій, які сприятимуть формуванню здоров'язбережувальної компетентності студентів; організація конструктивної взаємодії суб'єктів освітнього процесу, спрямованого на формування здоров'язбережувальної компетентності майбутніх фахівців соціальної роботи; проведення педагогічної діагностики сформованості студентів щодо здоров'язбережувальної компетентності; використання рефлексії (педагогічної та управлінської) в освітньому процесі 3BO.

\section{ЛIТЕРАТУРА}

1. Бойчук Ю. Д. Створення здоров'язберігаючого освітнього середовища як проблема сучасної освіти / Ю. Д. Бойчук // Наукові записки Кіровоградського державного педагогічного університету імені В. Винниченка. Серія: Педагогічні науки. - 2009. - Вип. 77. - С. 153-158.

2. Вакуленко О. В. Здоровий спосіб життя як соціально-педагогічна умова становлення особистості у підлітковому віці: автореф. дис... канд. пед. наук: 13.00.05 / О. В. Вакуленко. - К., 2001. - 26 с.

3. Григоренко Г. В. Здоров'ятворча компетентність підлітків та соціально-педагогічні умови іiі формування в діяльності загальноосвітнього навчального закладу / Г. В. Григоренко // Педагогічні науки: теорія, історія, інноваційні технології. - Суми: СумДПУ ім. А. С. Макаренка, 2015. - № 4 (48). - C. 215-222.

4. Гриценко В. А. Соціально-педагогічні умови подолання стану самотності студентів вищих навчальних закладів I-II рівнів акредитації: дис... канд. пед. наук: 13.00 .05 / В. А. Гриценко. - К., 2014. $-266 \mathrm{c}$. 
5. Ермаков С. С. Информационные аспекты здоровья и здорового образа жизни в электронном научном пространстве / С. С. Ермаков // Валеологія: сучасний стан, напрямки та перспективи розвитку. Матеріали III міжн. наук.-практ. конф. (квітень 2006, Харків). - Харків: ХНУ, 2006. C. 59-65.

6. Кальченко Л. В. Соціально-педагогічний захист бездоглядних дітей у притулках для дітей: наук.метод. посіб. / Л. В. Кальченко. - Луганськ: Луганськ. нац. ун-т. ім. Т.Г. Шевченка, 2010. - 348 с.

7. Козина Ж. Л. Гармоническое сочетание интеллектуального и физического развития как необходимое условие укрепления здоровья студентов и подготовки квалификованых спортсменов / Ж. Л. Козина, В. С. Ашанин // Физическое воспитание студентов творческих специальностей: сб. наук. трудов; под ред. проф. С. С. Ермакова. - Харьков: ХГАДИ (ХХПИ). 2007. - № 1. - С. 152156.

8. Лехолетова М. М. Формування здоров'язбережувальної компетентності майбутніх соціальних педагогів у процесі професійної підготовки: дис. ... канд. пед. наук: 13.00 .05 «Соціальна педагогіка» (Педагогічні науки) / М. М. Лехолетова. - К., 2018. - 270 с.

9. Носко Ю. М. Теоретичні аспекта застосування здоров'язбзрежувальних технологій у сучасній школі / Ю. М. Носко // Вісник Чернігівського національного педагогічного університету імені Т. Г. Шевченка. - Вип. 91. - Т. II. Серія: Педагогічні науки. Фізичне виховання та спорт. - 2011. C. $79-83$.

10. Оржеховська В. M. Здоров'язбережувальне навчання і виховання: проблеми, пошук / В. М. Оржеховська // Наукові записки НДУ імені М. Гоголя. Психолого-педагогічні науки. - 2011. - № 4. - С. 29-31.

11. Отравенко О. В. Організація інноваційної навчальної діяльності майбутніх фахівців 3 фізичного виховання через інтерграцію здоров'язбережувальних технологій / О. В. Отравенко // Науковий часопис Національного педагогічного університету імені М. П. Драгоманова. Серія 15. - 2014. Вип. 3(45). - 2014. - С. 249-253.

12. Отравенко О. В. Педагогічні умови формування здоров'язбережувальної компетентності учнівської та студентської молоді в умовах ступеневої освіти / О. В. Отравенко // Здоров'я, спорт, реабілітація. - Вип. 4. - 2016. - С. 47-50.

13. Чайковський М. Є. Соціально-педагогічні умови реабілітації студентів 3 особливими потребами: автореф. дис. ... канд. пед. наук: 13.00.05 / М. Є. Чайковський. - К., 2006. - 18 с.

14. Чернецька Ю. І. Соціально-педагогічні умови адаптації старших підлітків у загальноосвітніх санаторних школах-інтернатах: автореф. дис. ... канд. пед. наук: 13.00 .05 / Ю. І. Чернецька. Харків, 2008. - 22 с.

15. Штифурак В. Є. Соціально-педагогічні засади виховної роботи зі студентською молоддю у вищих навчальних закладах: автореф. дис. ... д-ра пед. наук: 13.00.05 / В. Є. Шрифурак. - Луганськ, 2011. $-46 \mathrm{c}$.

\section{REFERENCES}

1. Bojchuk, Ju. D. (2009). Stvorennia zdorovjazberighaiuchogho osvitniogho seredovyshha jak problema suchasnoi osvity. [Creating a Healthy Education Environment as a Problem of Modern Education]. Naukovi zapysky Kirovoghradsjkogho derzh. ped. un-tu imeni V. Vynnychenka. - Scientific notes of Kirovohrad V.Vinnichenko state. ped. University. Serija: Ped. nauky: zb. nauk. pracj. Kirovoghrad: RVV KDPU imeni V. Vynnychenka, Vyp. 77.4.2, pp. 153-158.

2. Vakulenko, O. V. (2001). Zdorovyi sposib zhyttia jak socialno-pedaghoghichna umova stanovlennja osobystosti u pidlitkovomu vici. Avtoreferat dis. ... kand. ped. nauk: spec. 13.00 .05 «Socialjna pedaghoghika». [Healthy Lifestyle as a Socio-Pedagogical Condition for Adolescence. Abstract PhD ped. sci. diss.]. Kyjiv. 26 p.

3. Ghryghorenko, Gh. V. (2015). Zdorov'jatvorcha kompetentnistj pidlitkiv ta socialjno-pedaghoghichni umovy ii formuvannja $\mathrm{v}$ dijaljnosti zaghaljnoosvitnjogho navchaljnogho zakladu. [Healthy competence of adolescents and social and pedagogical conditions of its formation in the activity of a comprehensive educational institution]. Pedaghoghichni nauky: teorija, istorija, innovacijni tekhnologhiji. - Pedagogical sciences: theory, history, innovative technologies. Sumy: SumDPU imeni A. S. Makarenka. Nr 4(48), pp. 215-222.

4. Ghrycenko, V. A. (2014). Socialjno-pedaghoghichni umovy podolannja stanu samotnosti studentiv vyshhykh navchaljnykh zakladiv I-II rivniv akredytacii. Dis. ... kand. ped. nauk: spec. 13.00.05 «Socialjna pedaghoghika». [Socio-pedagogical conditions of overcoming the state of loneliness of students of higher educational establishments of I-II levels of accreditation. PhD ped. sci. diss.]. Kyjiv. 266 p.

5. Ermakov, S. S. (2006). Ynformacyonnie aspekti zdorovia y zdorovogho obraza zhyzny v эlektronnom nauchnom prostranstve. [Informational aspects of health and a healthy lifestyle in the electronic scientific space]. Valeologhija: suchasnyj stan, naprjamky ta perspektyvy rozvytku. - Valeology: current state, directions and prospects of development. Materialy III mizhn. nauk.-prakt. konfer. (kvitenj 2006, Kharkiv). KhNU, pp. 59-65. 
6. Kaljchenko, L. V. (2010). Socialjno-pedaghoghichnyj zakhyst bezdoghljadnykh ditej u prytulkakh dlja ditej [Socio-pedagogical protection of street children in shelters for children science-method. tool.]: naukovo-metodychnyj posibnyk [scientific and methodological manual]. Lughansk: Lughansk. nac. un-t. im. T. G. Shevchenka. 348 p.

7. Kozina, Zh. L., Ashanin, V. S. (2007). Garmonicheskoe sochetanie intellektualnogo i fizicheskogo razvitiya kak neobkhodimoe uslovie ukrepleniya zdorovya studentov i podgotovki kvalifikovanykh sportsmenov. [A harmonious combination of intellectual and physical development as a necessary condition for strengthening the health of students and training qualified athletes]. Fizicheskoe vospitanie studentov tvorcheskikh spetsialnostey. - Physical education of students of creative specialties: Sb. nauk. trudov. Pod red. prof. S. S. Yermakova. Kharkov: KhGADI (KhKhPI). Nr 1, pp. 152-156.

8. Lekholetova, M. M. (2018). Formuvannja zdorov'jazberezhuvaljnoji kompetentnosti majbutnikh socialjnykh pedaghoghiv u procesi profesijnoji pidghotovky. Dis. ... kand. ped. nauk: spec. 13.00.05 «Socialjna pedaghoghika». [Formation of health-saving competence of future social educators in the process of vocational training. PhD ped. sci. diss.]. Kyjiv. 270 p.

9. Nosko, Ju. M. (2011). Teoretychni aspekty zastosuvannja zdorov'jazbzrezhuvaljnykh tekhnologhij u suchasnij shkoli. [Theoretical aspects of the use of health technologies in modern schools]. Visnyk Chernighivsjkogho nac. ped. un-tu imeni T. Gh. Shevchenka. - Bulletin of Chernihiv Taras Shevchenko National Pedagogical University. Vyp. 91. T. II. Serija: ped. nauky. Fizychne vykhovannja ta sport. Chernighiv: ChNPU, pp. 79-83.

10. Orzhekhovsjka, V. M. (2011). Zdorov'jazberezhuvaljne navchannja i vykhovannja: problemy, poshuk. [Health-saving education and training: problems, search]. Naukovi zapysky NDU imeni M. Ghogholja. Scientific notes of NGU named after M. Gogol. Psykhologho-pedaghoghichni nauky. Nr 4, pp. $29-31$.

11. Otravenko, O. V. (2014). Orghanizacija innovacijnoji navchaljnoji dijaljnosti majbutnikh fakhivciv z fizychnogho vykhovannja cherez interghraciju zdorov'jazberezhuvaljnykh tekhnologhij. [Organizing innovative training activities for future physical education professionals through the integration of healthsaving technologies]. Naukovyj chasopys Nac. ped. un-tu imeni M.P. Draghomanova. - Scientific journal of the National Pedagogical University named after M.P. Drahomanov. Serija 15: zb. nauk. pracj. Kyjiv: Vyd-vo NPU imeni M.P. Draghomanova, 2014. Vyp. ZK (45), pp. 249-253.

12. Otravenko, O. V. (2016). Pedaghoghichni umovy formuvannja zdorov'jazberezhuvaljnoji kompetentnosti uchnivsjkoji ta studentsjkoji molodi v umovakh stupenevoji osvity. [Pedagogical conditions of formation of health-saving competence of pupils and students in the conditions of stage education]. Zdorov'ja, sport, reabilitacija - Health, sports, rehabilitation. Vyp. 4, pp. 47-50.

13. Chajkovsjkyj, M. Je. (2006). Socialjno-pedaghoghichni umovy reabilitaciji studentiv z osoblyvymy potrebamy. Avtoreferat dis. ... kand. ped. nauk: spec. 13.00.05 «Socialjna pedaghoghika». [Socio-pedagogical conditions of rehabilitation of students with special needs. $\mathrm{PhD}$ abstract ped. sci. diss.]. Kyjiv. 18 p.

14. Chernecjka, Ju. I. (2008). Socialjno-pedaghoghichni umovy adaptaciji starshykh pidlitkiv u zaghaljnoosvitnikh sanatornykh shkolakh-internatakh. Avtoreferat dis. ... kand. ped. nauk: 13.00.05 «Socialjna pedaghoghika». [Socio-pedagogical conditions for adaptation of older adolescents in comprehensive boarding schools. PhD abstract ped. sci. diss.]. Kharkiv. 22 p.

15. Shtyfurak, V. Je. (2011). Socialjno-pedaghoghichni zasady vykhovnoji roboty zi studentsjkoju moloddju u vyshhykh navchaljnykh zakladakh. Avtoreferat dis. ... dokt. ped. nauk spec. 13.00 .05 «Socialjna pedaghoghika». [Socio-pedagogical principles of educational work with student youth in higher educational establishments. Dr. abstract ped. sci. diss.]. Luhansk. 46 p. 